\title{
Bacillus subtilis Extracellular Nuclease Production Associated with the spoOH Sporulation Locus
}

\author{
By WILLIAM F. BURKE, JR \\ Department of Botany and Microbiology, Arizona State University, Tempe, Arizona 85287 , \\ U.S.A.
}

(Received 7 October 1981: revised 21 October 1981)

\begin{abstract}
A number of nuclease-deficient mutants of Bacillus subtilis were isolated and found to be concurrently asporogenous. The nuclease-deficient phenotype appeared to be associated with the spoOH sporulation locus. Spontaneously occurring sporogenous revertants concomitantly recovered the ability to produce extracellular nuclease activity. The position of the $n c l$ mutation was determined using transformation and PBS1 transduction and found to map in the same site as spoOH. The map order of $n c l$ and markers in the vicinity was determined to be purA-cysA-ncl(spoOH)-strA.
\end{abstract}

\section{INTRODUCTION}

Under certain conditions cells of Bacillus subtilis undergo a process of rapid cell differentiation, culminating in the development of a complex intracellular structure, the bacterial endospore. This process appears to involve the activation of genes, or groups of genes, in a strict temporal sequence. This is truly a process of cell differentiation since it involves a sequence of profound morphological alterations accompanied by biochemical changes and by the synthesis of qualitatively new proteins.

Since sporulation proceeds by a primary dependent sequence of events, various genetic blocks introduced by mutations stop spore formation at various stages. Stage $O$ mutants remain similar to vegetative cells, showing no specific morphological signs of sporulation (Balassa, 1971). These types of mutants have been the subject of extensive genetic analysis (Hoch \& Mathews, 1973; Hoch et al., 1978; Piggot \& Coote, 1976). Each locus may have its own control elements and so be considered an operon (Piggot, 1973). It has been suggested that the products of the stage $\mathrm{O}$ loci may be involved in transcription and translation (Hoch et al., 1978). However, the function and products of many of these loci, including the spoOH locus, have remained unknown.

The studies presented in this paper identify a biochemical marker associated with the spoOH sporulation locus. This genetic locus is involved in the elaboration of four extracellular nucleases. These enzymes are exonucleolytic in nature and are elaborated during the earliest stages of sporulation (Slinker \& Burke, 1979, 1981).

\section{METHODS}

Bacterial strains. All bacterial strains used in this work were derivatives of $B$. subtilis 168 and are described in Table 1.

Mutagenesis. Nuclease-deficient mutants were obtained after mutagenesis of purified B. subtilis 168 spores with ethyl methanesulphonate (Ito \& Spizizen. 1971). Mutagenized spores were plated on minimal agar with tryptophan $\left(50 \mu \mathrm{g} \mathrm{ml}^{-1}\right)$ and incubated at $37^{\circ} \mathrm{C}$ for $3 \mathrm{~d}$. Colonies were then transferred to DNAase detection agar plates and incubated at $43^{\circ} \mathrm{C}$ for $2-3 \mathrm{~d}$.

Revertant selection. Sporogenous revertants of strain JH651 were obtained by growing the strain in Penassay Broth for $5 \mathrm{~h}$ at $37^{\circ} \mathrm{C}$ and $300 \mathrm{rev} . \mathrm{min}^{-1}$. The cells were collected by centrifugation at $10000 \mathrm{~g}$ for $15 \mathrm{~min}$ at 
Table 1. Bacillus subtilis strains

\begin{tabular}{|c|c|c|}
\hline Strain & Genotype & Origin \\
\hline 168 & $\operatorname{trp} C 2$ & J. Spizizen \\
\hline SR22 & $\operatorname{trpC2}$ spoOA12 & J. Spizizen \\
\hline IS 16 & trpC2 pheA1 spoOB136 & BGSC* \\
\hline IS 19 & $\operatorname{trpC} 2$ pheA1 spoOF 221 & BGSC \\
\hline IS20 & $\operatorname{trpC2}$ spoOH4 & BGSC \\
\hline IS22 & $\operatorname{trpC2} r f m-2$ spoOH 17 & BGSC \\
\hline JH651 & trpC2 pheA1 spoOH 1 & J. Hoch \\
\hline IS 27 & metC3 tal-1 spoOJ87 & BGSC \\
\hline IS 28 & $\operatorname{trpC2}$ spoOK14 & BGSC \\
\hline SCR2011 & cys $A 14$ str $A$ & J. Ito \\
\hline SCR2020 & leuA 8 metB5 purA16 & J. Ito \\
\hline ASB 164 & $\operatorname{trpC} 2 \mathrm{ncl}-1$ & This laboratory \\
\hline ASB 170 & $\operatorname{trpC2} n c l-2$ & This laboratory \\
\hline ASB 184 & $\operatorname{trpC} 2 \mathrm{ncl}-3$ & This laboratory \\
\hline
\end{tabular}

* BGSC, Bacillus Genetic Stock Center.

$4{ }^{\circ} \mathrm{C}$ and resuspended in $1 / 20$ the volume of minimal salts. Revertants were selected using a modification of the procedure of Hoch (1971). Samples were plated on sporulation plates containing the basal salts medium of Donnellan et al. (1964) supplemented with $0.1 \%(\mathrm{w} / \mathrm{v})$ glutamate, $0.1 \%(\mathrm{w} / \mathrm{v})$ casein hydrolysate, and $50 \mu \mathrm{g}$ phenylalanine $\mathrm{ml}^{-1}$ in glass Petri dishes. After $20 \mathrm{~h}$ incubation at $37^{\circ} \mathrm{C}$, the lawn of growth was killed by exposure to $2 \mathrm{ml}$ of chloroform pipetted into the lid of the inverted Petri dish. After the chloroform treatment, the plates were incubated at $37^{\circ} \mathrm{C}$ for $5 \mathrm{~d}$. This incubation allowed the spores formed by revertants to germinate, divide and form discrete colonies.

Transformation and transduction. Transformation experiments were carried out by the procedure of Anagnostopoulos \& Spizizen (1961). The DNA concentration was $0.02 \mu \mathrm{g}$ per $\mathrm{ml}$ of competent culture, and the cells were exposed to DNA for $30 \mathrm{~min}$. DNA was prepared by the method described previously (Burke \& Spizizen, 1977). PBS 1-mediated transduction was performed according to the method of Hoch et al. (1967) as modified by Young et al. (1969). Cells were grown in a motility medium consisting of minimal salts (Burke \& McCammon, 1978) supplemented with $0.5 \%(\mathrm{w} / \mathrm{v})$ yeast extract (Difco), $0.1 \%(\mathrm{w} / \mathrm{v})$ casein hydrolysate (Nutritional Biochemicals Corp.), $0.5 \%(\mathrm{w} / \mathrm{v})$ glucose, $5 \mathrm{~mm}-\mathrm{MgSO}_{4}$ and $50 \mu \mathrm{g}$ per ml of the auxotrophic requirements of the strain. Antibiotic selection, including overlay and expression time, was as described by Harford \& Sueoka (1970).

Nuclease assay. The procedure used for the quantitative assay of exonuclease activity was essentially that of Burke \& Spizizen (1977). The standard reaction mixture consisted of $0.1 \mathrm{M}-\mathrm{Tris} / \mathrm{HCl}(\mathrm{pH} 8.0), 10 \mathrm{~mm}-\mathrm{CaCl}_{2}$ and approximately $6.5 \mu \mathrm{g}\left[{ }^{3} \mathrm{H}\right] \mathrm{DNA} \mathrm{ml}{ }^{-1}$ (specific activity: 10157 c.p.m. per $\mu \mathrm{g}$ ) in a total volume of $0.29 \mathrm{ml}$. Following preincubation of the reaction mixture for at least $10 \mathrm{~min}$ at $37^{\circ} \mathrm{C}$, the reaction was initiated by the addition of a $10 \mu \mathrm{l}$ portion of the sample to be tested. After a 30 min incubation at $37{ }^{\circ} \mathrm{C}, 0.4 \mathrm{ml}$ of $7 \%(\mathrm{w} / \mathrm{v})$ perchloric acid and $0.4 \mathrm{ml}$ salmon sperm DNA solution $\left(5 \mathrm{mg} \mathrm{ml}^{-1}\right)$ were added. The solution was mixed, and then placed on ice for $30 \mathrm{~min}$. The sample was centrifuged at $12800 \mathrm{~g}$ for $2 \mathrm{~min}$ at room temperature, and $0.2 \mathrm{ml}$ of the resultant supernatant fluid was transferred to a scintillation vial containing $5 \mathrm{ml}$ of Aquasol (New England Nuclear). Radioactivity was measured using a Packard Tri-Carb 3320 liquid scintillation counter. A unit of DNAase activity is defined as the amount of enzyme catalysing the formation of $10 \mathrm{nmol}$ of acid-soluble nucleotides at $37^{\circ} \mathrm{C}$ in $30 \mathrm{~min}$.

DNAase detection agar. Agar plates for extracellular DNAase detection were prepared by adding $10 \mathrm{ml}$ salmon sperm DNA solution $\left(5 \mathrm{mg} \mathrm{ml}^{-1}\right)$ and $4 \mathrm{ml}$ acridine orange $\left(2 \mathrm{mg} \mathrm{ml}^{-1}\right)$ to $400 \mathrm{ml}$ of molten AK agar no. 2 medium supplemented with $1.6 \mathrm{~g}$ of agar. The mixture was incubated at $50^{\circ} \mathrm{C}$ for $1 \mathrm{~h}$ prior to pouring.

Sporulation media. Nutrient broth sporulation medium was essentially the same as that of Schaeffer's medium as modified by Leighton \& Doi (1971). The medium consisted of Difco nutrient broth $\left(16 \mathrm{mg} \mathrm{ml}^{-1}\right), 25 \mathrm{~mm}-\mathrm{KCl}$, $2 \mathrm{mM}-\mathrm{CaCl}_{2}, 10 \mu \mathrm{M}-\mathrm{FeSO}_{4}, 10 \mu \mathrm{M}-\mathrm{MnSO}_{4}, 0.1 \mathrm{~mm}-\mathrm{MgSO}_{4}$ and $5 \mathrm{~mm}$-glucose. The minimal salts sporulation medium of Donnellan et al. (1964) was also utilized in several experiments.

Sporulation test. Cells were grown in nutrient broth sporulation medium for $18 \mathrm{~h}$ at $37^{\circ} \mathrm{C}$ at $250 \mathrm{rev} \cdot \mathrm{min}^{-1}$ in a controlled environment incubator shaker (New Brunswick Scientific). For maximal aeration, the culture volume never exceeded $10 \%$ of the total flask volume. Viable cells were estimated by plating on tryptose blood agar base (TBAB, Difco). The heat-resistant colony-forming units were determined by first heating the culture for $10 \mathrm{~min}$ at $80^{\circ} \mathrm{C}$ and then plating on TBAB. 


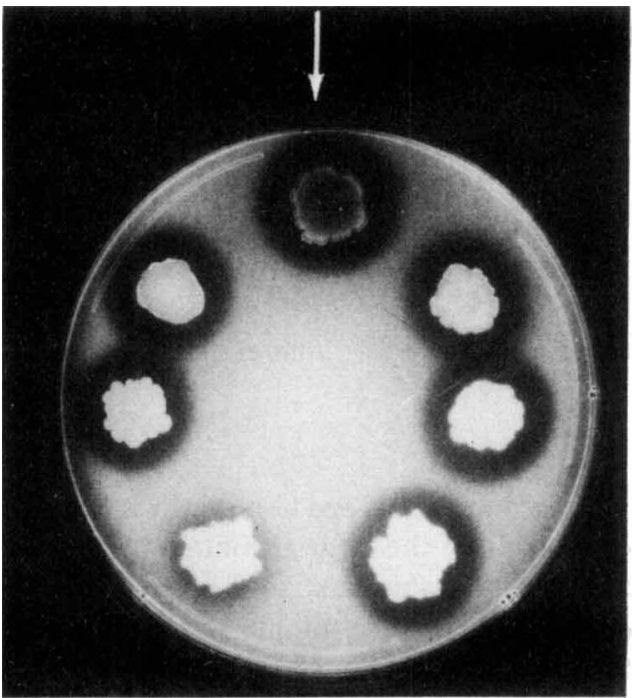

Fig. 1

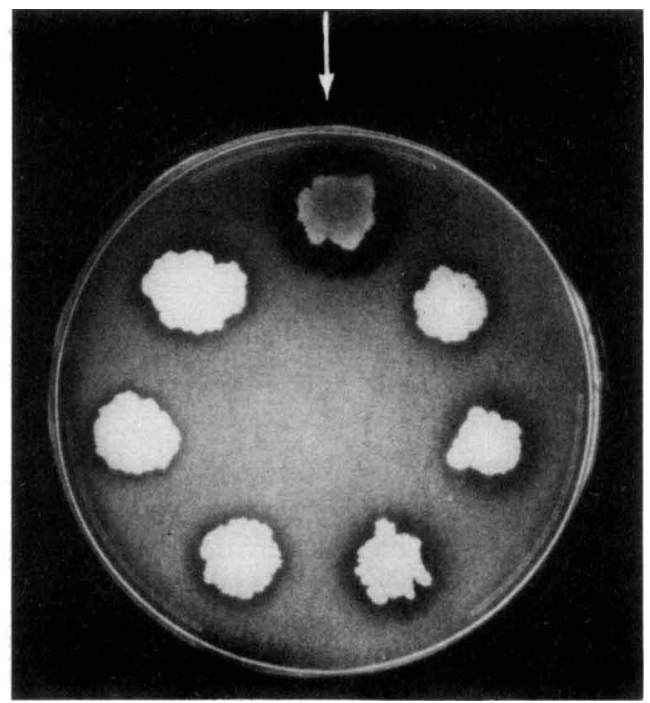

Fig. 2

Fig. 1. DNAase detection plate inoculated with a series of stage $O$ sporulation mutants. The strains were incubated at $43{ }^{\circ} \mathrm{C}$ for $48 \mathrm{~h}$. The dark areas around the colonies indicate extracellular nuclease activity. The arrow indicates the position of 168 (wild-type) at the top of the plate; SR22 (spoOA12), IS16 (spoOB 136), IS19 (spoOF221), JH651 (spoOH81), IS27 (spoOJ87) and IS28 (spoOK14) are positioned in a clockwise array from 168.

Fig. 2. DNAase detection plate inoculated with a series of spoOH and $n c l$ mutants. The arrow indicates the position of 168 (wild-type) at the top of the plate; IS20 (spoOH4), IS22 (spoOH17), JH651 (spoOH81), ASB164 (ncl-1), ASB170 (ncl-2) and ASB184 ( $n c l-3)$ are positioned in a clockwise array from 168 .

\section{RESULTS}

\section{Isolation of nuclease-deficient mutants}

In an effort to isolate mutants deficient in exonuclease production, spores of $B$. subtilis 168 were mutagenized with ethyl methanesulphonate. Isolated colonies from the mutagenized culture were transferred to DNA agar plates containing DNA and acridine orange in a sporulation agar. Following incubation at $43^{\circ} \mathrm{C}$ for $48 \mathrm{~h}$, the plates were examined under short-wave ultraviolet light. Dark, non-fluorescing areas were observed around the control colonies indicating extracellular exonuclease activity. Colonies which were deficient in nuclease production were detected by the absence of DNA hydrolysis in the vicinity of the colony. More than 30 nuclease-deficient mutants were isolated as the result of screening approximately 2500 colonies in this manner.

Two distinct mutant types were recognized among these nuclease-deficient strains. Approximately $25 \%$ of the mutants produced greatly reduced, although detectable, amounts of nuclease activity as observed on DNAase detection plates. All of these strains exhibited typical $\mathrm{Spo}^{+}$colony morphologies on AK sporulation medium, and refractile spores were observed upon microscopic examination. However, no attempts were made to determine whether these mutants were truly sporogenous or oligosporogenous; and, because of their variable behaviour on DNAase detection plates, further studies with these mutants were not pursued.

The remaining mutants appeared to be completely deficient in nuclease production on the DNAase detection medium. Mutants of this type were designated $\mathrm{ncl}$ and were found to be asporogenous. Three of these $\mathrm{ncl}$ mutants were chosen for further study.

In order to determine whether the nuclease deficiency in these mutants was related to the 
Table 2. Sporulation and nuclease activities of spoOH revertants

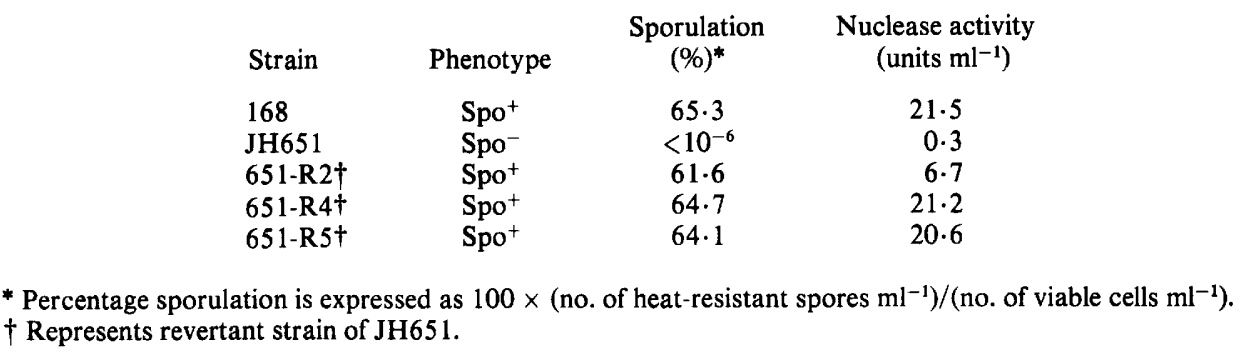

sporulation deficiency, a series of strains with well characterized stage $O$ mutations were also examined for nuclease production. With one exception, all of the stage $O$ mutants tested were able to synthesize nuclease (Fig. 1). The exception was a strain mutated in the $\mathrm{spoOH}$ locus of the $B$. subtilis chromosome. Next, a series of well defined spoOH mutants were examined to determine if this nuclease deficiency was a general property of spoOH mutants. All of the spoOH mutants tested were deficient in nuclease production (Fig. 2).

A number of spontaneously occurring sporogenous revertants of the nuclease-deficient strains were examined for their ability to produce nuclease using DNAase detection agar. All of the Spo ${ }^{+}$revertants of JH651 (6/6), ASB164 (74/74), ASB170 (48/48) and ASB 184 $(89 / 89)$ demonstrated nuclease production on the detection plates. Three of the spontaneously occurring $\mathrm{Spo}^{+}$revertants of JH651 (spoOH81 ncl-81) were studied further in order to quantify the sporulation frequencies and extracellular nuclease levels. It was determined that these revertants had regained the ability to sporulate simultaneously with the ability to synthesize extracellular nuclease (Table 2).

\section{Mapping of ncl mutations}

The location of the spoOH locus is well established (Hoch \& Mathews, 1973; Piggot, 1973; Piggot \& Coote, 1976) and is situated between cysA14 and strA on the genetic map. Since preliminary experiments with the DNAase detection agar indicated that the nuclease gene might be associated with the spoOH locus, mapping experiments were concentrated in the region of this sporulation locus.

PBS 1 transductions localized the $n c l$ mutations between the purA and $\operatorname{str} A$ loci. The $n c l$ mutations were found to weakly cotransduce with purA16 at frequencies of between 4 and $10 \%$. Three-factor crosses indicated that the $n c l$ markers were all closely linked to the cys $A 14$ locus and were tentatively located on the side of the cysA14 locus proximal to $\operatorname{str} A$ (Table 3 ). However, the high frequency of cotransduction of the $n c l$ mutations with cys $A 14$ made accurate location difficult. Unequivocal ordering of the $\mathrm{ncl}$ mutations relative to the $c y s A 14$ locus was not possible from these data. Transformation crosses were undertaken to clarify these results. The mapping data obtained for the spoOH81 locus and the $n c l$ mutations in the three-factor transformation crosses are consistent with the transduction data (Table 4). Reciprocal transformation crosses into the poorly competent spoOH and ncl mutants failed to provide useful information. Inasmuch as Piggot (1973) has positioned the $s p o O H$ locus just to the right of cysA14, the sequence cysA14-ncl-strA is assumed.

In all of the experiments described above, inheritance of the nuclease deficiency was completely correlated to the acquisition of the $\mathrm{Spo}^{-}$phenotype. This result further supports the supposition that the production of nuclease is an integral function of the $s p o O H$ locus. From the data presented here, it is not possible to determine whether the $\mathrm{spoOH}$ locus contains the structural gene for the nuclease or whether the nuclease deficiency is a pleiotropic effect of mutation of the spoOH locus. Because the spoOH and $n c l$ strains were poorly competent, mutual transformation crosses between strains carrying the $s p o O H$ or $n c l$ 
Table 3. Three-factor crosses by PBSI transduction for mapping nuclease deficiency mutations

\begin{tabular}{|c|c|c|c|c|c|c|c|}
\hline \multirow{2}{*}{$\begin{array}{l}\text { Donor } \\
\text { spoOH81 }\end{array}$} & \multirow{3}{*}{$\begin{array}{l}\text { Recipient } \\
\text { cysA14 strA }\end{array}$} & \multirow{2}{*}{$\begin{array}{c}\text { Selected } \\
\text { marker } \\
\mathrm{Cys}^{+}\end{array}$} & \multicolumn{3}{|c|}{ Recombinant classes* } & $\begin{array}{l}\text { No. of } \\
\text { recombinants }\end{array}$ & Marker order \\
\hline & & & cysA14 & spoOH8I & strA & & \\
\hline & & & 1 & 1 & 1 & 10 & \\
\hline & & & 1 & 1 & 0 & 238 & cysA 14-spoOH81--strA \\
\hline & & & 1 & 0 & 1 & 14 & \\
\hline & & & 1 & 0 & 0 & 0 & \\
\hline \multirow[t]{5}{*}{$n c l-1$} & cysA14 strA & $\mathrm{Cys}^{+}$ & cysAl4 & $n c l-1$ & strA & & \\
\hline & & & 1 & 1 & 1 & 13 & \\
\hline & & & 1 & 1 & 0 & 191 & $\operatorname{cys} A 14-n c l-1--\operatorname{str} A$ \\
\hline & & & 1 & 0 & 1 & 12 & \\
\hline & & & 1 & 0 & 0 & 0 & \\
\hline \multirow[t]{5}{*}{$n c l-2$} & cysA14 strA & Cys $^{+}$ & cys $A 14$ & $n c l-2$ & strA & & \\
\hline & & & 1 & 1 & 1 & 5 & \\
\hline & & & 1 & 1 & 0 & 198 & cys $A 14-n c l-2--s t r A$ \\
\hline & & & 1 & 0 & 1 & 10 & \\
\hline & & & 1 & 0 & 0 & 0 & \\
\hline \multirow[t]{5}{*}{$n c l-3$} & cysA14 strA & $\mathrm{Cys}^{+}$ & cysA14 & $n c l-3$ & strA & & \\
\hline & & & 1 & 1 & 1 & 12 & \\
\hline & & & 1 & 1 & 0 & 112 & cysA14-ncl-3--strA \\
\hline & & & 1 & 0 & 1 & 10 & \\
\hline & & & 1 & 0 & 0 & 0 & \\
\hline \multirow[t]{5}{*}{ strA cysA14 } & spoOH81 & $\operatorname{Str}^{R}$ & strA & spoOH81 & cys $A 14$ & & \\
\hline & & & 1 & 1 & 1 & 155 & \\
\hline & & & 1 & 1 & 0 & 2 & cysA14-spoOH81--strA \\
\hline & & & 1 & 0 & 1 & 0 & \\
\hline & & & 1 & 0 & 0 & 29 & \\
\hline \multirow[t]{5}{*}{ strA cys $A 14$} & $n c t-1$ & $\mathrm{Str}^{\mathrm{R}}$ & strA & $n c l-1$ & cysA14 & & \\
\hline & & & 1 & 1 & 1 & 152 & \\
\hline & & & 1 & 1 & 0 & 2 & cysA $14-n c l-1--s t r A$ \\
\hline & & & 1 & 0 & 1 & 0 & \\
\hline & & & 1 & 0 & 0 & 28 & \\
\hline \multirow[t]{5}{*}{ strA cysA14 } & $n \mathrm{cl}-2$ & $\operatorname{Str}^{R}$ & strA & $n c l-2$ & $\operatorname{cys} A 14$ & & \\
\hline & & & 1 & 1 & 1 & 144 & \\
\hline & & & 1 & 1 & 0 & 9 & cys $A 14-n c l-2--s t r A$ \\
\hline & & & 1 & 0 & 1 & 0 & \\
\hline & & & 1 & 0 & 0 & 28 & \\
\hline \multirow[t]{5}{*}{$\operatorname{str} A \operatorname{cys} A 14$} & $n \mathrm{cl}-3$ & $\operatorname{Str}^{\mathrm{R}}$ & strA & $n c l-3$ & cysA14 & & \\
\hline & & & 1 & 1 & 1 & 125 & \\
\hline & & & 1 & 1 & 0 & 3 & cysA 14-ncl-3--strA \\
\hline & & & 1 & 0 & 1 & 0 & \\
\hline & & & 1 & 0 & 0 & 22 & \\
\hline
\end{tabular}

mutations did not contribute to the understanding of the relationship between these mutations.

\section{DISCUSSION}

Mutants deficient in extracellular nuclease production were isolated from mutagenized $B$. subtilis 168 spores. Examination of a number of stage $\mathrm{O}$ sporulation mutants indicated that the extracellular enzyme production was in some way associated with the spoOH locus.

Spontaneous reversion to the $\mathrm{Spo}^{+}$phenotype resulted in concomitant recovery of exonuclease production. Genetic mapping of three of the $n c l$ mutants isolated in this study, in addition to the well characterized spoOH81 strain, suggested the following arrangement of loci on the chromosome: purA-cysA-ncl(spoOH)-strA (Fig. 3). 


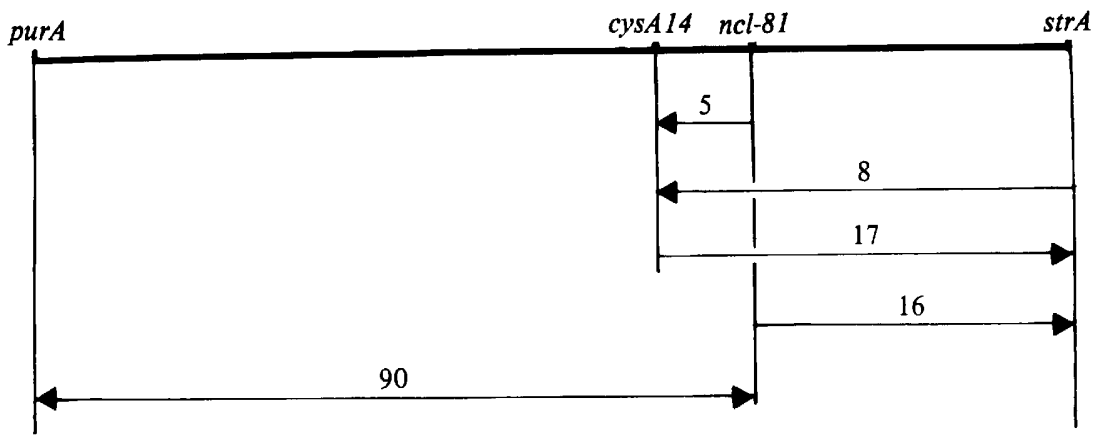

Fig. 3. Location of the $n c l-81$ (spoOH81) mutation on the B. subtilis genetic map. Distances between markers are expressed as percentage of recombination according to the convention: \% recombination $=(1-$ cotransfer $) \times 100$. The arrow heads point to selected markers.

Table 4. Three-factor transformation crosses for mapping nuclease deficiency mutation

\begin{tabular}{|c|c|c|c|c|c|c|c|}
\hline \multirow{3}{*}{$\begin{array}{l}\text { Donor } \\
\text { spoOH81 }\end{array}$} & \multirow{2}{*}{$\begin{array}{c}\text { Recipient } \\
\text { cysA14 strA }\end{array}$} & \multirow{2}{*}{ 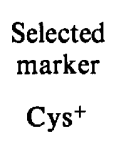 } & \multicolumn{3}{|c|}{ Recombination classes* } & $\begin{array}{l}\text { No. of } \\
\text { recombinants }\end{array}$ & Marker order \\
\hline & & & cysA14 & spoOH81 & strA & & \\
\hline & & & 1 & 1 & 1 & 97 & \\
\hline & & & 1 & 1 & 0 & 102 & cysA14-spoOH8l--strA \\
\hline & & & 1 & 0 & 1 & 14 & \\
\hline & & & 1 & 0 & 0 & 44 & \\
\hline \multirow[t]{5}{*}{$n c l-1$} & cys $A 14$ strA & Cys $^{+}$ & cysA14 & $n c l-1$ & strA & & \\
\hline & & & 1 & 1 & 1 & 27 & \\
\hline & & & 1 & 1 & 0 & 129 & cysAl4-ncl-1--strA \\
\hline & & & 1 & 0 & 1 & 21 & \\
\hline & & & 1 & 0 & 0 & 59 & \\
\hline \multirow[t]{5}{*}{$n c l-2$} & cysA14 strA & $\mathrm{Cys}^{+}$ & cysA14 & $n c l-2$ & strA & & \\
\hline & & & 1 & 1 & 1 & 31 & \\
\hline & & & 1 & 1 & 0 & 148 & cysA14-ncl-2--strA \\
\hline & & & 1 & 0 & 1 & 12 & \\
\hline & & & 1 & 0 & 0 & 48 & \\
\hline \multirow[t]{5}{*}{$n c l-3$} & cys $A 14$ strA & $\mathrm{Cys}^{+}$ & cys $A 14$ & $n c l-3$ & strA & & \\
\hline & & & 1 & 1 & 1 & 45 & \\
\hline & & & 1 & 1 & 0 & 120 & cys $A 14-n c l-3--s t r A$ \\
\hline & & & 1 & 0 & 1 & 21 & \\
\hline & & & 1 & 0 & 0 & 44 & \\
\hline
\end{tabular}

At present no conclusive evidence is available to indicate that the $n c l$ mutations are mutations in the structural gene of the nuclease. It is possible that the failure to produce extracellular nucleases early in sporulation results from a pleiotropic effect of a mutation in the $s p o O H$ locus. Indeed, mutations of the $s p o O H$ locus preclude the synthesis of all four nuclease forms. However, it is interesting to note that the $\mathrm{Ncl}^{-}$phenotype, unlike many other sporulation properties, appears to be associated with only one stage $O$ locus. Further, of the approximately 2500 colonies examined in screening $\mathrm{ncl}$ mutants, not one nuclease-deficient, sporogenous mutant was observed.

Akrigg \& Mandelstam (1978) have demonstrated that during sporulation B. subtilis 168 also produces a manganese-stimulated endodeoxyribonuclease that is released into the medium. The production of this nuclease is associated with events late in stage II of sporulation. The nucleases associated with $\mathrm{spoOH}$ function are exonucleolytic in nature and preferentially degrade single strand DNA (Slinker \& Burke, 1979). These $n c l$ controlled nucleases are thought to be the nucleases described by Kerr et al. (1965) and Kanamori et al. 
(1973). Although these enzymes have ribonuclease capabilities, they do not represent the major form of ribonuclease associated with the early stages of sporulation.

The data obtained in this study are consistent with the supposition that the production of the extracellular exonuclease activity observed early in sporulation is determined in some way by genetic information located in the spoOH locus. This DNAase production provides an easily measurable biochemical property characteristic of the $s p o O H$ locus.

This work was supported in part by Public Health Service grant GM-25343 from the National Institute of General Medical Sciences and by the Faculty Grant-in-Aid Program, Arizona State University. I am grateful to Barbara S. Slinker for her expert technical assistance with certain aspects of this work.

\section{REFERENCES}

AkRigG, A. \& Mandelstam, J. (1978). Extracellular manganese stimulated deoxyribonuclease as a marker event in sporulation of Bacillus subtilis. Biochemical Journal 172. 63-67.

Anagnostopoulos, C. \& Spizizen, J. (1961). Requirements for transformation in Bacillus subtilis. Journal of Bacteriology 81, 741-746.

Balassa, G. (1971). The genetic control of spore formation in bacilli. Current Topics in Microbiology. and Immunology 56, 99-192.

Burke, W. F., JR \& MCCAMmon, M. (1978). Ultraviolet sensitivity of Bacillus subtilis citD mutants. Current Microbiology 1. 167-170.

BURKe, W. F., JR \& SpIzIzEN. J. (1977). Isolation. characterization, and activation of the magnesiumdependent endodeoxyribonuclease from Bacillus subtilis. Biochemistry 16, 403-410.

Donnellan, J. R.. JR. Nags, E. H. \& Levinson, H. S. (1964). Chemically defined synthetic media for sporulation and for germination and growth of Bacillus subtilis. Journal of Bacteriology' 87, 332336.

Harford, N. \& Sueoka, N. (1970). Chromosomal location of antibiotic resistance markers in Bacillus subtilis. Journal of Molecular Biology 51.267-286.

Hoch, J. A. (1971). Selection of cells transformed to prototrophy for sporulation markers. Journal of Bacteriolog.' 105, 1200-1201.

Hoch, J. A. \& MATHEws, J. L. (1973). Chromosomal location of pleiotropic negative sporulation mutations in Bacillus subtilis. Genetics 73, 215-228.

Hoch. J. A., Barat, M. \& Anagnostopoulos, C. (1967). Transformation and transduction in recombination-defective mutants of Bacillus subtilis. Journal of Bacteriology 93. 1925-1937.

Hoch. J. A.. Shiflett, M. A.. Trowsdale. J. \& Chen, S. M. H. (1978). Stage O genes and their properties. In Spores VII. pp. 127-130. Edited by G. Chambliss \& J. C. Vary. Washington. D.C.: American Society for Microbiology.
Ito, J. \& SPIZIZEN, J. (1971). Increased rate of asporogenous mutations following treatment of Bacillus subtilis spores with ethyl methanesulfonate. Mutation Research 13, 93-96.

Kanamori, N., Sakabe, K. \& OKazaki, R. (1973). Extracellular nucleases of Bacillus subtilis. I. Purification and properties. Biochimica et biophysica acta 335, 155-172.

Kerr, I. M., Pratt, E. A. \& Lehman, I. R. (1965). Exonucleolytic degradation of high-molecularweight DNA and RNA to nucleoside $3^{\prime}$-phosphate by a nuclease from $B$. subtilis. Biochemical and Biophysical Research Communications 20, 154162.

Leighton, T. J. \& DoI, R. H. (1971). The stability of messenger ribonucleic acid during sporulation in Bacillus subtilis. Journal of Biological Chemistry 246, 3189-3195.

Piggot, P. J. (1973). Mapping of asporogenous mutations of Bacillus subtilis: a minimum estimate of the number of sporulation operons. Journal of Bacteriology 114, 1241-1253.

Piggot, P. J. \& Coote, J. G. (1976). Genetic aspects of bacterial endospore formation. Bacteriological Reviews 40, 908-962.

Slinker, B. S. \& Burke, W. F., JR (1979). Calcium-dependent exonucleases of Bacillus subtilis. Abstracts, 79th Annual Meeting of the American Society for Microbiology, Los Angeles, California, abstract K-34.

Slinker, B. S. \& BUrke, W. F., JR (1981). Isolation and characterization of a manganese-stimulated exonuclease from Bacillus subtilis. Current Microbiology 5, 23-26.

Young, F. E., Smith, C. \& Reilly, B. E. (1969). Chromosomal location of genes regulating resistance to bacteriophage in Bacillus subtilis. Journal of Bacteriology 98, 1087-1097. 